Dept. of Food Hygiene,

Animal Health Research Institute, Dokki, Giza

\title{
EVALUATION OF CONTACT SURFACES CONTAMINATION IN SMOKED SALMON PLANT AND ITS EFFECT ON THE FINAL PRODUCT \\ (With 3 Tables)
}

By

\section{AMANI L.F. AHMED and K.M. EL-KHAWAS}

(Received at 8/9/2008)

تقدير مدى تلوث الاسطح الملامسة للاسماك فى مصانع السالمون المدخن

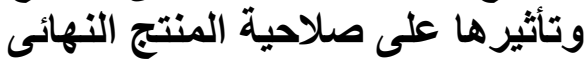

أمانح لطفى فرج أحد ، خالد محد سبي الخواص

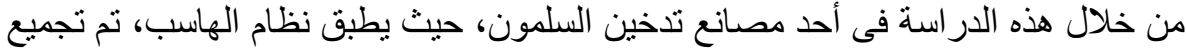

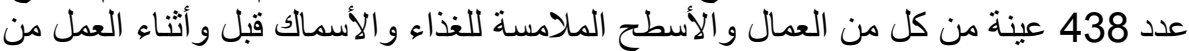

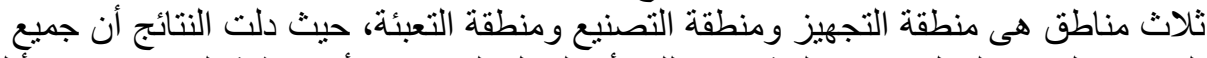

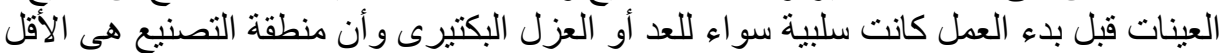

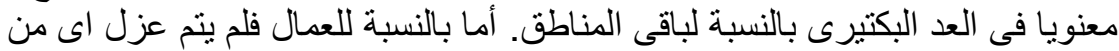

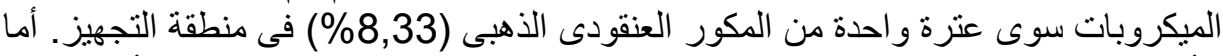

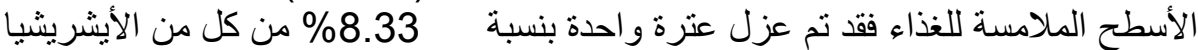

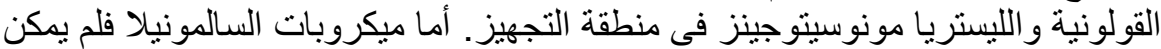

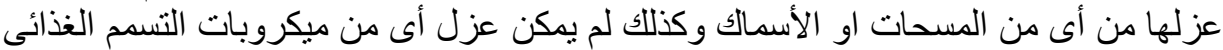

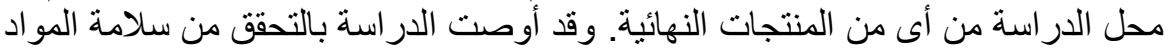

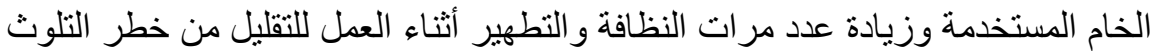

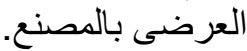

\section{SUMMARY}

A total number of 438 workers, surface swabs and fish samples were collected from cold-smoked salmon plant where HACCP system is in place. The samples were collected pre- and during work from three areas (preparing, processing and packaging) to be examined for the bacterial count and isolation of food poisoning microorganisms (Salmonella, E. coli, S. aureus and L. monocytogenes). All the preworking samples were negative for count and isolation. Meanwhile the production area was significantly $(\mathrm{P}<0.05)$ lower in count for both workers and contact 
surfaces swabs than the other areas during work. For workers samples only $S$. aureus $(1,8.33 \%$ ) was isolated from preparing area, while other microorganisms couldn't be isolated. For contact surfaces one strain (8.3\%) of each of E. coli and L. monocytogenes were isolated from preparing area. Meanwhile, E. coli $(1,8.3 \%)$ and L. monocytogenes $(2,16.7 \%)$ were isolated from fish samples in the preparing area. Salmonella couldn't be isolated from any sample. Raw materials were the most probable cause of contamination. None of the investigated microorganisms was isolated from the finished products. For such plant, it's recommended to verify the quality of purchased raw material and to decrease the intervals of sanitization program to decrease the risk of cross contamination.

Key words: Fish, Salmon, smoked fish, Salmonella, L.monocytogenes.

\section{INTRODUCTION}

Smoking is among the oldest methods of food preservation. Smoked salmon as one of the ready-to-eat (RTE) seafood has been recorded as a vehicle for pathogenic microorganisms and food poisoning outbreaks occasionally occur. Improper processing and lack of suitable storage condition of these products is the main cause of food poisoning outbreaks (Gudbjornsdottir et al., 2004; Eklund et al., 2004).

Hazard analysis critical control point "HACCP" is becoming established and has been successful in the food industry, and improving the control of food production in catering establishments (MartinezTome et al., 2000). The hygiene of the process and processing environment is a significant factor in the production of microbiologically safe and good quality products in the fish industry. Both quantity and the specific type of microbial flora are important factors for evaluating the hygiene of the processing environment (Miettinen et al., 2001).

Although food poisoning microorganisms has been isolated from fresh frozen, and processed seafood, the production of RTE cold smoked salmon represents a particular concern, since the processing of these products does not include a thermal inactivation step (Ward, 2001). Meanwhile, salting represents the only weak bactericidal step (Neunlist et al., 2005).

L. monocytogenes can contaminate finished products through employee contact surfaces such as hand tools, gloves, aprons, and food contact surfaces (Tompkin et al., 1999). FDA identified smoked fish in 
the high risk category for causing listeriosis. L. monocytogenes can cause listeriosis in pregnant women, immuncompromized and eldery (Slutsker and Schuchat, 1999). There are several reports of listeriosis associated with the consumption of RTE foods (Anon, 2001). Some of these epidemics resulted in mortalities, as well as large scale recalls of implicated RTE foods (USDA, 2002). Listeriosis has a mortality rate of 20-30\% and thus represents a serious public health concern (Schuchat, et al., 1991). The prevalence of Listeira spp. in RTE foods have been variable ranging from $1.8 \%$ to $48 \%$ (Gibbons et al., 2006).

Other enteric pathogens have been isolated form RTE foods including E. coli and Salmonella emphasizing the risk posed by consumption of these foods (Faustini et al., 2003; Lee and Middleton, 2003). In many countries $S$. aureus is the second or third common cause of foodborne disease outbreaks behind Salmonella (Rosec et al., 1997). S. aureus was the predominant microorganism found on hands of food preparators (Ryan et al., 1996). Scott and Bloomfield (1990) identified the ability of $S$. aureus to cause cross-contamination for up to $24 \mathrm{~h}$ via the fingertips.

The aim of this study was to determine the level of food contact surface hygiene and occurrence of Listeria spp. Salmonella spp., E. coli and $S$. aureus and its effect on the final product in cold-smoked salmon factory where HACCP system is implemented.

\section{MATERIALS and METHODS}

In a cold-smoked salmon plant where HACCP system is in place, the processing steps were as follows; imported eviscerated whole frozen salmon fishes were left to thaw in a cold room (less than $10{ }^{\circ} \mathrm{C}$ ), washed with water and acetic acid, deheaded, cut into two halves, deboned, salted then smoked (cold smoking), trimmed, sliced and finally vacuum packed.

Through six visits, a total number of 438 samples were collected as follows: 126 consisted of 36 workers and 90 food contact surfaces swabs were collected pre-work directly after cleaning and disinfection. Another 252 samples consisted of 72 workers, 180 food contact surface swabs and 60 food samples were collected during at least midway through a shift and towards the end of the working day from various processing stages. All swabbed surfaces were in direct contact with food. The plant was divided into three areas representing preparing area, processing area and packaging area. Each area was sampled for workers 
(gloves and aprons), surfaces [utensils (tables, knives, containers, shovels and cutting boards), machines (skinning, trimming and slicing)] and fish (frozen, thawed, salted, smoked and final packed product). Swabs from workers' hands and $25 \mathrm{~cm}^{2}$ from food contact surfaces using sterile swab moisten with neutralizing buffer and 25 grams of food were collected. All samples were kept in an icebox and transported without delay to the laboratory where they were analyzed for the following:

\section{Bacteriological analysis:}

- Preparation of samples

On arrival to the laboratory, samples were homogenized with buffer peptone (1:10). Ten-fold serial dilutions were prepared using buffer peptone for the following analysis:

1. Aerobic plate count: using pour plate technique onto plate count agar (Oxoid, CM0325) and incubation at $35{ }^{\circ} \mathrm{C}$ for $48 \mathrm{~h}$ according to APHA (1992).

2. Isolation of Salmonella: samples were pre-enriched on buffer peptone for $24 \mathrm{~h}$ at $37{ }^{\circ} \mathrm{C}$, enriched on Rappaport Vassiliadis (Lab M 86) for $24 \mathrm{~h}$ at $41.5{ }^{\circ} \mathrm{C}$ and tetrathionate broth (Oxoid CM0029) at $37{ }^{\circ} \mathrm{C}$ for $24 \mathrm{~h}$ then plated on XLD (Oxoid CM0469) and Brilliant green agar at $37{ }^{\circ} \mathrm{C}$ for $24 \mathrm{~h}$, according to APHA (1992).

3. Isolation of E. coli: using lauryl sulphate broth (Biolife) incubated at $35{ }^{\circ} \mathrm{C}$ for $24-48 \mathrm{~h}$ followed by inoculation of a loopful from positive tubes on E. coli broth (Britania) incubated at $45.5^{\circ} \mathrm{C}$ for $24-48 \mathrm{~h}$ then plated on eosin methylene blue agar (Biolife) and incubated at $35^{\circ} \mathrm{C}$ for 24-48 $\mathrm{h}$ according to APHA (1992).

4. Isolation of $S$. aureus: using selective enrichment procedure, by enrichment on brain heart infusion broth (Oxoid CM225) at $37{ }^{\circ} \mathrm{C}$ for $24 \mathrm{~h}$, then streaking on Barid Parker agar (Biolife) at $35^{\circ} \mathrm{C}$ for $48 \mathrm{~h}$ according to APHA (1992).

5. Isolation of L. monocytogenes: using Listeria enrichment broth (Biolife) at $30{ }^{\circ} \mathrm{C}$ for $48 \mathrm{~h}$ and plating on Oxford agar (Lab M 122) at $35^{\circ} \mathrm{C}$ for $24-48 \mathrm{~h}$ according to FAO (1992)

The results were statistically analysed according to Selvin 1996), using SPSS for Windows version 10. "SPSS Inc. Headquarters, Chicago, Illinois USA". 


\section{RESULTS}

Table 1: Mean APCs and incidence of isolated microorganisms in different areas for workers samples

\begin{tabular}{|c|c|c|c|c|c|c|c|c|c|c|}
\hline \multirow[t]{2}{*}{ Area } & \multirow[t]{2}{*}{ Samples } & \multicolumn{2}{|c|}{ No. } & \multicolumn{2}{|r|}{ APC } & \multicolumn{5}{|c|}{ Isolates No. (\%) } \\
\hline & & B & D & B & D & B & E. coli & \begin{tabular}{|c|}
$L$. \\
monocytogenes
\end{tabular} & S. aureus & Salmonella \\
\hline $\begin{array}{l}\text { Preparing } \\
\text { area }\end{array}$ & $\begin{array}{r}\text { Workers } \\
\text { Gloves } \\
\text { Aprons }\end{array}$ & \begin{tabular}{l|}
12 \\
6 \\
6
\end{tabular} & $\begin{array}{l}24 \\
12 \\
12\end{array}$ & -ve & $\begin{array}{r}2.5 \times 10^{2} \mathrm{a} \\
2.0 \times 10^{2} \\
3.0 \times 10^{2}\end{array}$ & -ve & -ve & -ve & $1(8.33 \%)$ & -ve \\
\hline $\begin{array}{l}\text { Production } \\
\text { area }\end{array}$ & $\begin{array}{r}\text { Workers } \\
\text { Gloves } \\
\text { Aprons }\end{array}$ & \begin{tabular}{|l|}
12 \\
6 \\
6 \\
\end{tabular} & $\begin{array}{l}24 \\
12 \\
12\end{array}$ & -ve & $\begin{array}{c}8.0 \mathrm{X} 10 \mathrm{~A} \\
5.0 \mathrm{X} 10 \\
1.1 \mathrm{X} 10^{2}\end{array}$ & -ve & -ve & -ve & -ve & $-\mathrm{Ve}$ \\
\hline $\begin{array}{l}\text { Packing } \\
\text { area }\end{array}$ & $\begin{array}{r}\text { Workers } \\
\text { Gloves } \\
\text { Aprons }\end{array}$ & \begin{tabular}{|l|}
12 \\
6 \\
6 \\
\end{tabular} & $\begin{array}{l}24 \\
12 \\
12\end{array}$ & -ve & \begin{tabular}{|c}
$1.0 \times 10^{2} \mathrm{a}$ \\
$8.0 \mathrm{X} 10$ \\
$1.2 \times 10^{2}$
\end{tabular} & -ve & -ve & -ve & -ve & -ve \\
\hline
\end{tabular}

B: before work

D: during work

There is significant difference between means containing the same capital and small letter

Table 2: Mean APCs and incidence of isolated microorganisms in different areas for surfaces samples

\begin{tabular}{|c|c|c|c|c|c|c|c|c|c|c|}
\hline \multirow[t]{2}{*}{ Area } & \multirow[t]{2}{*}{ Samples } & \multicolumn{2}{|c|}{ No. } & \multicolumn{2}{|r|}{ APC } & \multicolumn{5}{|c|}{ Isolates No. (\%) } \\
\hline & & B & D & B & D & B & E. coli & $\begin{array}{c}L . \\
\text { monocytogenes }\end{array}$ & $\begin{array}{c}S . \\
\text { aureus }\end{array}$ & Salmonella \\
\hline $\begin{array}{l}\text { Preparing } \\
\text { area }\end{array}$ & $\begin{array}{l}\text { Utensils } \\
\text { Tables } \\
\text { Knives } \\
\text { Containers } \\
\text { Cutting- } \\
\text { boards } \\
\end{array}$ & $\begin{array}{c}24 \\
6 \\
6 \\
6 \\
6\end{array}$ & $\begin{array}{l}48 \\
12 \\
12 \\
12 \\
12\end{array}$ & -ve & \begin{tabular}{|c|}
$6.0 \times 10^{2} \mathrm{a}$ \\
$3.0 \times 10^{2}$ \\
$2.2 \times 10^{2}$ \\
$1.0 \times 10^{3}$ \\
$9.0 \times 10^{2}$
\end{tabular} & -ve & $\begin{array}{c}- \\
- \\
- \\
1(8.3 \%)\end{array}$ & $\begin{array}{c}- \\
- \\
1(8.3 \%) \\
-\end{array}$ & -ve & -ve \\
\hline $\begin{array}{l}\text { Production } \\
\text { area }\end{array}$ & $\begin{array}{l}\text { Utensils } \\
\text { Tables } \\
\text { Shovels } \\
\text { Containers } \\
\text { Shelves }\end{array}$ & $\begin{array}{c}24 \\
6 \\
6 \\
6 \\
6\end{array}$ & $\begin{array}{l}48 \\
12 \\
12 \\
12 \\
12\end{array}$ & -ve & \begin{tabular}{|c}
$1.1 \times 10^{2} \mathrm{~A}$ \\
$1.0 \times 10^{2}$ \\
$2.0 \times 10$ \\
$2.4 \times 10^{2}$ \\
$8.0 \times 10$
\end{tabular} & -ve & -ve & $-\mathrm{ve}$ & $-\mathrm{ve}$ & -ve \\
\hline $\begin{array}{c}\text { Packing } \\
\text { area }\end{array}$ & \begin{tabular}{|c|} 
Surface \\
Machines \\
Skinning \\
Trimming \\
Slicing \\
Utensils \\
Tables \\
Knives \\
Containers \\
Cutting- \\
boards
\end{tabular} & \begin{tabular}{|c|}
42 \\
18 \\
6 \\
6 \\
6 \\
24 \\
6 \\
6 \\
6 \\
6
\end{tabular} & $\begin{array}{l}84 \\
36 \\
12 \\
12 \\
12 \\
48 \\
12 \\
12 \\
12 \\
12\end{array}$ & -ve & $\begin{array}{c}3.9 \times 10^{2} \mathrm{a} \\
3.0 \times 10^{2} \\
2.0 \times 10^{2} \\
2.1 \times 10^{2} \\
5.0 \times 10^{2} \\
4.8 \times 10^{2} \\
6.0 \times 10^{2} \\
4.3 \times 10^{2} \\
3.0 \times 10^{2} \\
6.0 \times 10^{2}\end{array}$ & -ve & $-\mathrm{ve}$ & $-\mathrm{ve}$ & -ve & $-\mathrm{ve}$ \\
\hline
\end{tabular}

There is significant difference between means containing the same capital and small letter 
Table 3: Mean APCs and incidence of isolated microorganisms in different areas for food samples

\begin{tabular}{|c|c|c|c|c|c|c|c|}
\hline \multirow{2}{*}{ Area } & Samples & No. & APC & \multicolumn{4}{|c|}{ Isolates No. (\%) } \\
\cline { 3 - 8 } & & & $\mathrm{D}$ & E. coli & $\begin{array}{c}\text { L. } \\
\text { monocytogenes }\end{array}$ & $\begin{array}{c}\text { S. } \\
\text { aureus }\end{array}$ & Salmonella \\
\hline \multirow{2}{*}{ Preparing area } & Frozen & 12 & $5.4 \times 10^{2} \mathrm{~A}$ & - & $2(16.7 \%)$ & $-\mathrm{ve}$ & $-\mathrm{ve}$ \\
& Thawed & 12 & $1.2 \times 10^{4} \mathrm{a}$ & $1(8.3 \%)$ & - & & \\
\hline \multirow{2}{*}{ Production area } & Salted & 12 & $2.0 \times 10^{2} \mathrm{~A}$ & $-\mathrm{ve}$ & $-\mathrm{ve}$ & $-\mathrm{ve}$ & $-\mathrm{ve}$ \\
& Smoked & 12 & $4.3 \times 10^{3} \mathrm{a}$ & $-\mathrm{ve}$ & $-\mathrm{ve}$ & & \\
\hline \multirow{2}{*}{ Packing area } & Final & 12 & $6.2 \times 10^{3} \mathrm{a}$ & $-\mathrm{ve}$ & $-\mathrm{ve}$ & $-\mathrm{ve}$ & -ve \\
\hline
\end{tabular}

There is significant difference between means containing the same capital and small letter

\section{DISCUSSION}

The pre-work samples of the food contact surfaces and workers swabs for the 3 sampled areas were negative for aerobic plate count and isolation (Table 1, 2 and 3). This result indicates the efficiency of the processes of cleaning and disinfection SSOPs (sanitary standard operating procedures). On the other hand, the bacterial loads for workers, utensils and machines were significantly elevated during work in the different three areas.

This result is reasonable considering that HACCP system is established at the plant i.e. food hygiene training of the staff, physical separation of raw food materials and unpacked smoked salmon by means of separate areas, utensils and machines, the use of separate staff, control and monitoring of temperature. This result agrees with Gillespie et al., (2000) who stated that significantly unsatisfactory or unacceptable samples were obtained from premises where no HACCP system was in place as compared with these which had an undocumented or documented hazard analysis system.

Results highlighted that raw salmon was the most probable cause of contamination of each of workers (hands and aprons), machines and utensils during work. This indication can be observed from the bacterial count of frozen and thawed salmon (Table, 3). The condition that emphasize the spread of bacteria in the working environment during preparing salmon fishes. This result agrees with Gorman et al. (2002) who observed that contaminated raw materials contributed to an increase in the contamination level of worker's hands, counter tops and draining 
boards during preparation. Also held the opinion of Eklund et al. (1995) who stated that sanitation and cleanup procedures adequately eliminated L. monocytogenes from the processing line and equipment, but recontamination occurred soon after resumption of processing. The primary source of contamination proved to be the surface areas of frozen or fresh raw fish coming into the plant.

Results of bacterial load of food contact surfaces (workers and surfaces) and fish samples showed weak but significant $(\mathrm{P}<0.05)$ decrease in the production area than preparing and packing areas (Table 1, 2 and 3). This decrease can be attributed to the washing effect of thawed fishes (raw material) with acetic acid beside the effect of salting. This result agrees with that recorded by (Neunlist et al., 2005).

Prior to food preparation, all workers' hands, machines and utensils were free of all the tested microorganisms. However, after preparation and processing L. monocytogenes was isolated from the containers in preparation area $(1(8.3 \%)$ (Table, 2$)$. The pathogen could also be isolated from $2(16.7 \%)$ of frozen fishes (Table, 3$)$. This agrees to some extent with Cabedo et al. (2008) who isolated L. monocytogenes from $20 \%$ of frozen fishes.

The ability of foodborne microorganisms as Salmonella and Listeria spp. to become disseminated from naturally contaminated foods to various hands and food contact surfaces is well known (Gorman et al., 2002). Throughout the present study we observed that in spite of the studied plant applied restrict sanitary programs according to HACCP system L. monocytogenes could be isolated from utensils. The same findings were achieved by several studies which have shown that L. monocytogenes is capable of contaminating food processing machines with bacterial attachment and biofilm formation representing a source of potential contamination of food products (Autio et al. 1999). Once attached to a surface, L. monocytogenes appear to be more difficult to be removed (Autio et al., 1999 and Beresford et al., 2001).

Although L. monocytogenes was isolated from the preparation area and frozen fishes it couldn't be isolated from other surfaces or finished products. This could be attributed to the effective SSOPs and the combined effect of processing steps (washing with acetic acid, salting and smoking). This correspond with the opinion of Neunlist et al. (2005) who stated that the combination of steps of cold-smoking significantly lowered L. monocytogenes by $1.6 \mathrm{log} \mathrm{cfu} / \mathrm{g}$. Also Gonzalez et al. (2002) couldn't isolate the organism from any of the samples of 
smoked salmon. On the other hand, Cabedo et al. (2008) isolated L. monocytogenes from $7.9 \%$ of smoked salmon.

It was observed through this study that $S$. aureus was the only isolated pathogen from one worker's apron (8.33\%) after preparation of raw fishes. In this concern, Gorman et al. (2002) achieved the same result and claimed that $S$. aureus was the predominant microorganism found on hands of food preparators following food preparation. Food preparator hands were recorded as the main factor contributing up to $39 \%$ of domestic food poisoning outbreaks (Ryan et al., 1996). Scott and Bloomfield (1990) identified the ability of the $S$. aureus to cause cross contamination for up to 24 hours via fingers' tips.

E. coli could be isolated from $1(8.3 \%)$ of the cutting boards (preparation area) and from $1(8.3 \%)$ of thawed fishes. It seems that the cleaning process eliminated the pathogen so it couldn't be isolated from any of the finished products. This result agrees with Gonzalez et al. (2002) who couldn't isolate E. coli from the smoked salmon samples. In this concern, Gorman et al. (2002) reported that from 7 isolates of E. coli during the preparation of food, four of which were found to cross contaminate one or more of the premises surfaces such as counter top and draining boards.

Although Salmonella has been found to survive on dry surfaces for long periods of time (Humphrey et al., 1994) it couldn't be detected in the examined raw food premises surfaces or final products. In the same way, Gonzalez et al. (2002) couldn't isolate Salmonella from the smoked salmon samples. However, Gorman et al. (2002) reported that a small number of Salmonella infected food (8\%) had the ability to cause $100 \%$ cross contamination with other sites in the preparing premises including the counter top.

It was obvious in the present study that all the final products were negative for all the tested pathogens although the raw food materials and some of the processing facilities were contaminated. The result which indicates the proper and efficiency of the production processes. At the same time, such a plant may need to decrease the intervals between cleaning and sanitization item to increase its ability to eradicate pathogens such as L. monocytogenes.

Overall, it was undoubtful that the contaminated raw food material is the real cause of disseminating microorganisms and contamination of various facilities (equipments and utensils) and workers' hands. Therefore, it is recommended to verify the quality of purchased raw material and to increase frequency of cleaning and 
disinfecting of the premises and the hygienic practice of the workers to decrease the risk of cross contamination.

\section{REFERENCES}

Anonymous (2001): Report of Nordic workshop on L. monocytogenes. Copenhagen, 26-27 September, the workshop financed by the Nordic committee of senior officials for food issues, project No. 68.10.48 Project Leader Savenquist, Denmark.

APHA (1992): Compendium of Methods for the Microbiological Examination of Foods. Vanderzant, C. and Splittstoesser, D.F. (eds.). $3^{\text {rd }}$ ed. Pp. 75, 325, 370, Edwards Brothers, Washington, DC. USA.

Autio, T.; Hielm, S.; Mittinen, M.; Sjoberg, A.M.; Aarnisalo, K.; Bjorkroth, J.; Mattiasandholm, T. and Korkeala, H. (1999): Sources of L. monocytogenes contamination in a cold smoked rainbow trout processing plant detected by pulsed field gel electrophoresis typing. Appl. Environ. Microbiol. 65: 150-155.

Beresford, M.R.; Andrew, P.W. and Shama, G. (2001):

L. monocytogenes attaches to many materials found in food processing environment. J. Appl. Bacteriol. 90: 1000-1005.

Cabedo, L.; Picarti, I.; Barrot, L. and CAneles, A. (2008): Prevalence of Listeria monocytogenes and Salmonella in ready-to-eat food in Catalonia, Spain. J. Food Prot. 71 (4): 855-859.

Eklund, M.W.; Peterson, M.E.; Poysky, F.F.; Paranjpye, R.N and Pelroy, G.A. (2004): Control of bacterial pathogens during processing of cold-smoked and dried salmon strips. J. Food Prot. 67 (2): 347-351.

Eklund, M.W.; Poysky, F.T.; Paranjpye, R.N.; Lashbrook, L.C.; Peterson, M.E. and Pelroy, G.A. (1995): Incidence and sources of Listeria monocytogenes in cold-smoked fishery products and processing plants. J. Food Prot. 58 (5): 502-508.

FAO (1992): Manual of Food Quality Control. Part 4: Microbiological Analysis. Pp. 127. FAO, Rome

Faustini, A.; Rossi, P.G. and Perucci, C.A. (2003): Foodborne outbreak control teams. Outbreaks of foodborne diseases in the Lazio region, Italy: The results of the epidemiological field investigations. Eur. J. Epidemiol. 18: 699-702. 
Gibbons, I.; Adesiyun, A.; Seepersadsingh, N. and Rahman, S. (2006): Investigation for possible source(s) of contamination of readyto-eat meat products with Listeria spp. and other pathogens in a meat processing plant in Trinidad. Food Microbiol. 23: 359366.

Gillespie, I.; Little, C. and Michell, R. (2000): Microbial examination of cold ready-to-eat sliced meats from catering establishments in the United Kingdom. J. Appl. Microbiol. 88: 467-74.

Gonzalez-Rodriguez, M.N; Sanz, J.J.; Santos, J.A.; Otero, A. and Garcia-Lopez, M.L. (2002): Numbers and types of microorganisms in vacuum-packed cold-smoked freshwater fish at the retail level. Int. J. Food Microbiol. 77 (1-2):161-168.

Gorman, R.; Bloomfield, S. and Adley, C.C. (2002): A study of crosscontamination of foodborne pathogens in the domestic kitchen in the Republic of Ireland. Int. J. Microbiol. 76: 143-150.

Gudbjornsdottir, B.; Suihko, M.L.; Gustavsson, P.; Thorkelsson, G.; Salo, S.; Sjoberg, A.M.; Niclassen, O. and Brdholt, S. (2004): The incidence of L. monocytogenes in meats, poultry and seafood plants in Nordic countries. Food Microbiol. 21, 217225.

Humphrey, T.J.; Martin, K.W. and Whitehead, A. (1994): Contamination of hands and work surfaces with Salmonella enteritidis PT4 during the preparation of egg dishes. Epidemiology and Infection, 24 (261-264.

Lee, M.B. and Middleton, D. (2003): Enteric illness in Ontario Canada from 1997 to 2001. J. Food Prot. 66: 953-961.

Martinez-Tome, M.; Vera, A.M. and Murcia, M.A. (2000): Improving the control of food production in catering establishments with particular reference to the safety of salads. Food Control, 11, 437-445.

Miettinen, H.; Aarnisalo, K.; Salo, S. and Sjöberg, A.M. (2001): Evaluation of surface contamination and the presence of Listeria monocytogenes in fish processing factories. J. Food Prot. 64(5): 635-639.

Neunlist, M.R.; Ralazamahaleo, M.; Cappelier, J.M.; Besnard, V.; Federighi, M. and Leroi, F. (2005): Effect of salting and coldsmoking process on the culturability, viability and virulence of Listeria monocytogenes strain Scott A. j. Food Prot. 68 (1): 8591. 
Rosec, J.P.; Guiraud, J.P.; Dalet, C. and Richard, N. (1997): Enterotoxin production by staphylococci isolated from foods in France. Int. J. Food Microbiol. 35: 213-221.

Ryan, M.J.; Wall, P.G.; Gilbert, R.J.; Griffin, M. and Rowe, B. (1996): Risk factors for outbreaks of infectious intestinal disease linked to domestic catering. Communicable Disease Report 6 (13), R 179-183.

Schuchat, A.B.; Swaminathan, and Broome, C.V. (1991): Epidemiology of human listeriosis. Clin. Microbiol. Res. 4: 169-183.

Scott, E. and Bloomfield, S.F. (1990): The survival and transfer of microbial contamination via cloths, hands and utensils. J. Appl. Bacteriol. 68: 271-278.

Selvin, W. (1996): Statistical Analysis of Epidemiologic Data. $2^{\text {nd }}$ ed. Pp. 53-55 Oxford University Press, New York.

Slutsker, L. and Schuchat, A. (1999): Listeriosis in humans. P. 75-95. In E.T. Ryser and E. H. Marth (ed.) Listeria, Listeriosis and Food Safety. Pp. 77. Marcel Dekker, New York.

Tompkin, R.B.; Scott, V.N.; Bernard, D.T.; Sveum, W.H. and Gambas, K.S. (1999): Guidelines to prevent post processing contamination from L. monocytogenes. Dairy Food Environ. Sanit. 19: 551-562.

USDA (2002): USDA provides update on Listeria recall. Release No. 0445.02. www.usda.gov.

Ward, D.R. (2001): Description of the situation. In: Processing parameters needed to control pathogens in cold smoked fish. J. Food Sci. suppl. 66: S1067-1071. 